RESEARCH ARTICLE

\title{
CHARACTERISTICS OF CORN COBS WASTE ACTIVATED CARBON FOR SLOW RELEASE MICRO FERTILIZER CARRIER
}

\author{
Priyadi and Windu Mangiring \\ Agricultural College of Dharma Wacana Metro, Jl. Kenanga No.3, Mulyojati, Metro Barat, Kota Metro, \\ Lampung 34121, Indonesia
}

Submitted: 2018-12-05 Accepted: 2019-10-22

\begin{abstract}
The problem of fertilization, especially micro fertilizers, is toxication due to the excessive application. Using the concept of slow release fertilizer is a very possible solution to overcome the problem. The objectives of this study are 1) to characterize corn cobs activated carbon for slow release micro fertilizer carrier, 2) to produce and to test of slow release micro fertilizer. The research was carried out by converting corn cobs into activated carbon with an activation temperature of $600{ }^{\circ} \mathrm{C}$ and water vapor for 90 minutes. Production of slow release fertilizer was carried out by soaking activated carbon in a solution of $\mathrm{CuSO}_{4}, \mathrm{FeSO}_{4}$ and $\mathrm{ZnSO}_{4} 1 \mathrm{~N}$ for 24 hours. The results of micro fertilizer were then characterized, then the solubility test was carried out. The results of the characteristic analysis showed that some parameters that could be used as fertilizer carriers include, iodine adsorption $404.21 \mathrm{mg} \mathrm{g}^{-1}$, adsorption of methylene blue $16.88 \mathrm{mg} \mathrm{g}^{-1}$, the pore volume of $0.19 \mathrm{cc} \mathrm{mg}^{-1}$ and surface area of $315.77 \mathrm{~m}^{2} \mathrm{~g}^{-1}$. While, based on the results of micronutrient solubility test the highest nutrient content that can be absorbed by activated carbon (AA) is found in $\mathrm{Cu}$, followed by $\mathrm{Zn}$ and Fe. It relates to the characteristics possessed by activated carbon namely specific surface area, pore volume, and nutrient diameter size.
\end{abstract}

Keywords: Activated carbon, Adsorption carrier, Corn cobs, Slow release

How to Cite: Priyadi and Mangiring, W. (2019). Characteristics of Corn Cobs Waste Activated Carbon for Slow Release Micro Fertilizer Carrier. Sains Tanah Journal of Soil Science and Agroclimatology, 16(2): 147-158 (doi: 10.20961/stjssa.v16i2.25480)

Permalink/DOI: http://dx.doi.org/10.20961/stjssa.v16i2.25480

\section{INTRODUCTION}

Maize is a type of carbohydrateproducing annual crop besides wheat and rice which is widely cultivated in Lampung Province.

* Corresponding Author:

Email: priyadigege@ymail.com
According to BPS-Statistics of Lampung Province (2013), the area of harvested corn crops reached 346,315 hectares. The high demand for carbohydrate sources, especially corn, also demanded an increase in corn production. On the other hand, the use of corn as food ingredient also increase corn 
production, which is also including corn cobs waste that has not been optimally utilized.

At this time, agricultural waste including stover and corn cobs began to be used as biomass (Graham et al. 2007). One of the uses of waste is as raw material for bioenergy (Zych, 2008); as absorbent of rhodamine $b$ and methanil yellow (Munawaroh, 2012), dye of methylene blue (Al Tufaily \& Al Qadi, 2016), substitute for animal feed especially ruminants (Bunyamin et al., 2013), as an animal feedstock preserved in the form of silage (McCutcheon \& Samples, 2002) and low cost adsorbent from agricultural waste (Tsai et al., 1998). Seeing the potential, it does not rule out the possibility to be used as a basic material of micro fertilizer carrier. The use of micro fertilizer is chosen because it becomes a problem if given excessively. This utilization can be done by turning the corn cobs into activated carbon.

Activated carbon is charcoal which has a configuration of carbon atoms free of other elemental bonds and the pores are free of impurities so that it can increase adsorption ability (Keech et al., 2005). Activated carbon is a highly adsorptive material that has a complex structure composed of atoms carbon (Amin \& Alazba, 2017). Adsorption occurs because the molecules will be trapped in the structure of carbon internal pore by Van Der Waals Forces or other bonds of attraction and they will be accumulated into a solid surface (Singh \& Ambika, 2018). Utomo et al. (2012) and (Hayashi et al., 2013) revealed that using activated carbon can increase the efficiency of fertilization in rice plants. In addition, Laird et al. (2010) explain that the use of activated carbon can reduce nutrient loss in the soil due to increased cation exchange capacity from the addition of activated carbon. Furthermore, (Clough \& Condron, 2010) revealed that activated carbon has the ability to manipulate $\mathrm{N}$ cycle levels in soil systems by influencing the rate of nitrification, ammonia adsorption, and increasing $\mathrm{NH}_{4}{ }^{+}$deposits through soil CECs, thereby reducing $\mathrm{N}$ loss in the form of $\mathrm{N}_{2} \mathrm{O}$ gas and reducing nitrate leaching. Research by Namgay et al. (2010) shows that activated carbon application can reduce the availability of trace elements ( $\mathrm{Pb}, \mathrm{Cu}, \mathrm{Cd}, \mathrm{Zn}$, and $\mathrm{As})$ in plants. Due to this matter, activated carbon is the potential material for slow release micro fertilizer carrier.

At the present time, there is little information about the use of activated carbon as a carrier in slow release. Several studies only focused on the classification for controlling slow release, namely organic compound, water-soluble fertilizer with a physical barrier and inorganic compound (Shaviv, 2001); (Trenkel, 2010). Blaylock et al. (2005) however, classified CRFs as only two major types; those coated with low solubility compounds and those coated with water-soluble materials. Besides, the fertilizer used as slow release material is still limited to macronutrients such as N, P, and K (Du et al., 2006; Adegbidi et al., 2003). With the ability possessed by activated carbon to absorb toxic elements (Rao et al., 2009), heavy metals (Buah et al., 2016) and metal ions in water bodies (Rao et al., 2009), activated carbon can be used as a carrier. Based on the description above, the objectives of this research are to characterize the activated carbon from corn cobs as a carrier of slow release micro fertilizer and to produce as well as to test micro fertilizer slow release. 


\section{MATERIALS AND METHODS}

The research was carried out in the laboratory of Agricultural college of Dharma Wacana Metro from June 2017 to March 2018. The research began with the prototype of micro fertilizer slow release by utilizing activated carbon from corn cobs. Activated carbon characterization and micro fertilizer test was carried out by the Agricultural Environment Research Institute and the Integrated Laboratory Unit and the Technology Innovation Center of Lampung University.

The materials used in the research consisted of raw materials for the production of activated carbon, materials mixed for producing micro fertilizer slow release and various chemical reagents for analysis. The raw material used in this study is corn cobs for active carbon. The material mixed into activated carbon for the manufacture of slow release fertilizer namely $\mathrm{CuSO}_{4} \cdot 5 \mathrm{H}_{2} \mathrm{O}, \mathrm{FeSO}_{4}$, and $\mathrm{ZnSO}_{4}$.

The tools used are scales, drum furnace, electric retort and steamer, Wiley mill, oven, furnace, Scanning Electron Microscope-Energy Dispersive X-ray (SEM-EDX) EVO MA 10, Microwave plasma-atomic emission spectrometry (MP-AES) Agilent 4200, and glass tools for chemical analysis.

\section{Procedure}

Converting raw materials to charcoal

The corn cobs used in this study were collected from Metro, province of Lampung. Corn cobs are ground and sieved to about $0.015-0.30 \mathrm{~mm}$ in size and drying at $110^{\circ} \mathrm{C}$ in an oven until a constant weight is reached before carbonization (Buah et al., 2016). Then, the charcoal production process is carried out using a drum furnace with a capacity of $90 \mathrm{~kg}$. The drum furnace is filled with raw materials (known for its weight) placed on small pieces of wood that have been stored first at the base of the drum furnace. The combustion is carried out at a temperature that increases gradually to a temperature of $\pm 500{ }^{\circ} \mathrm{C}$. After all the raw material in the furnace burns completely, which is characterized by the decreasing of the smoke coming out of the furnace and the changing color of the smoke into bluish color, the combustion is stopped by tightly closing all the paths that the air passes into the furnace. Furthermore, the cooling process is carried out in the furnace for \pm 24 hours (National Standardization Agency of Indonesia, 1995).

Activated carbon production and characterization

Activated carbon production is carried out by inserting carbonized charcoal into an electric retort and activated with water vapor at a temperature of $600{ }^{\circ} \mathrm{C}$ for 90 minutes. The activated carbon that has been produced is then weighed, finely ground until it passes a 100 mesh sieve screen and analyzed based on SNI 06-3730-1995 which includes: rendemen, water content, levels of flying substances, ash content, activated carbon content, adsorption of iodine, and adsorption of methylene blue (National Standardization Agency of Indonesia, 1995).

\section{Production of slow release fertilizer}

Activated carbon that has been obtained is mashed to 100 mesh. Fertilizer preparation is done by soaking the activated carbon in a fertilizer solution for \pm 24 hours with the amount 
of concentration used is $1000 \mathrm{ppm}$. Then the immersion results were washed until sulfate free was tested by dripping $\mathrm{BaCl}_{2} 0.5 \mathrm{~N}$ and then dried. After obtaining dry powder fertilizer, further analysis was carried out by covering surface topography observations using Scanning Electron Microscope-Energy Dispersive X-ray (SEM-EDX) EVO MA 10. Further testing is carried out to determine the release of nutrients in fertilizer (Yang et al., 2011).

\section{Nutrient release test}

This experiment aims to determine the release of $\mathrm{Cu}^{2+}, \mathrm{Fe}^{2+}$ and $\mathrm{Zn}^{2+}$ elements in fertilizer. The experiment was carried out in two ways, the first method was extracting fertilizer with distilled water extract (fertilizer ratio: extractor $=1: 5$ ) with some extraction time which was $0 ; 20 ; 40 ; 60$; and 80 minutes. The second method is by leaching the fertilizer. The leaching process is carried out by flowing $25 \mathrm{ml}$ of distilled water in 5 grams of fertilizer in filter paper which is placed in the funnel 25 times. The results of the leaching process were then dried. After that, a qualitative analysis was performed using SEM-EDX MA 10 and the amount of nutrient release with MP-AES Agilent 4200 (Kamala et al., 2014).

\section{RESULTS}

\section{Activated Carbon Characteristics}

The results of charcoal characterization and activated carbon analysis based on SNI 063730-1995 are presented in Table 1. Based on Table 1, can be seen some characteristics of activated carbon. The rendemen produced from the activation process was lower compared to the activated carbon rendemen. Activated carbon rendemen was obtained $17.12 \%$ while charcoal was obtained at $21.22 \%$. Charcoal flying substance levels decreased after the activation process. The decreasing occurred was around $1 \%$ namely $16.33 \%$ to $15.32 \%$. Carbon content bound to activated carbon is higher than charcoal. The amount level of bounded carbon produced in activated carbon was higher $(63.37 \%)$ than in charcoal (57.54\%).

Surface area and total pore volume of activated carbon increase with temperature ascension in the activation process. The surface area of corn cob charcoal was $139.23 \mathrm{~m}^{2} \mathrm{~g}^{-1}$, while for activated carbon with an activation temperature of $600{ }^{\circ} \mathrm{C}$ was $315.77 \mathrm{~m}^{2} \mathrm{~g}^{-1}$.

Table 1. Results of carbon characterization analysis at $350^{\circ} \mathrm{C}$ and activated carbon $600{ }^{\circ} \mathrm{C}$

\begin{tabular}{|c|c|c|c|c|c|c|c|c|c|c|}
\hline No & Parameters & $\begin{array}{c}\text { Rendemen } \\
\text { (\%) }\end{array}$ & $\begin{array}{c}\text { Moisture } \\
\text { Content } \\
\text { (\%) }\end{array}$ & $\begin{array}{c}\text { Flying } \\
\text { substance } \\
\text { levels (\%) }\end{array}$ & $\begin{array}{c}\text { Ash } \\
\text { content } \\
\text { (\%) }\end{array}$ & $\begin{array}{c}\text { Fixed } \\
\text { carbon } \\
(\%)\end{array}$ & $\begin{array}{c}\text { lodine } \\
\text { adsorption } \\
\left(\mathrm{mg} \mathrm{g}^{-1}\right)\end{array}$ & $\begin{array}{l}\text { Methylene blue } \\
\text { adsorption } \\
\left(\mathrm{mg} \mathrm{g}^{-1}\right)\end{array}$ & $\begin{array}{l}\text { Total Pore } \\
\text { Volume } \\
\left(\mathrm{cc} \mathrm{g}^{-1}\right)\end{array}$ & $\begin{array}{c}\text { Surface } \\
\text { area } \\
\left(\mathrm{m}^{2} \mathrm{~g}^{-1}\right)\end{array}$ \\
\hline 1 & $A$ & 21.22 & 5.63 & 16.33 & 5. 95 & 57.54 & 112.30 & 4.25 & 0.12 & 139.23 \\
\hline 2 & AA & 17.12 & 3.67 & 15.32 & 5.47 & 63.37 & 404.21 & 16.88 & 0.19 & 315.77 \\
\hline
\end{tabular}

Description:

A: Corn cobs carbon temperature of $350{ }^{\circ} \mathrm{C}$

AA: Activated carbon of corn cobs activation temperature of $600{ }^{\circ} \mathrm{C}$ 
Priyadi and Mangiring / SAINS TANAH - Journal of Soil Science and Agroclimatology, 16(2), 2019, 151

Table 2. Nutrient solubility test of micro fertilizers slow release

\begin{tabular}{llrrrrrr}
\hline & & \multicolumn{4}{c}{ level $(\mathbf{p p m})$ at the time of matching } & \multirow{2}{*}{$\begin{array}{c}\text { Total solubility } \\
\text { No. }\end{array}$} & Parameters
\end{tabular}

The total pore volume of corn cobs charcoal was $0.12 \mathrm{cc} \mathrm{g}^{-1}$ and $0.19 \mathrm{cc} \mathrm{g}^{-1}$ for activated carbon from corn cobs. Other characteristics that play a role in the ability of activated carbon as a carrier are surface morphology. Surface morphology can show both the cavity formed and the presence of nutrients added to activated carbon. The explanation can be seen from the results of SEM analysis (Figure 1) and EDX (Figure 2, Figure 3, Figure 4, and Figure 5).
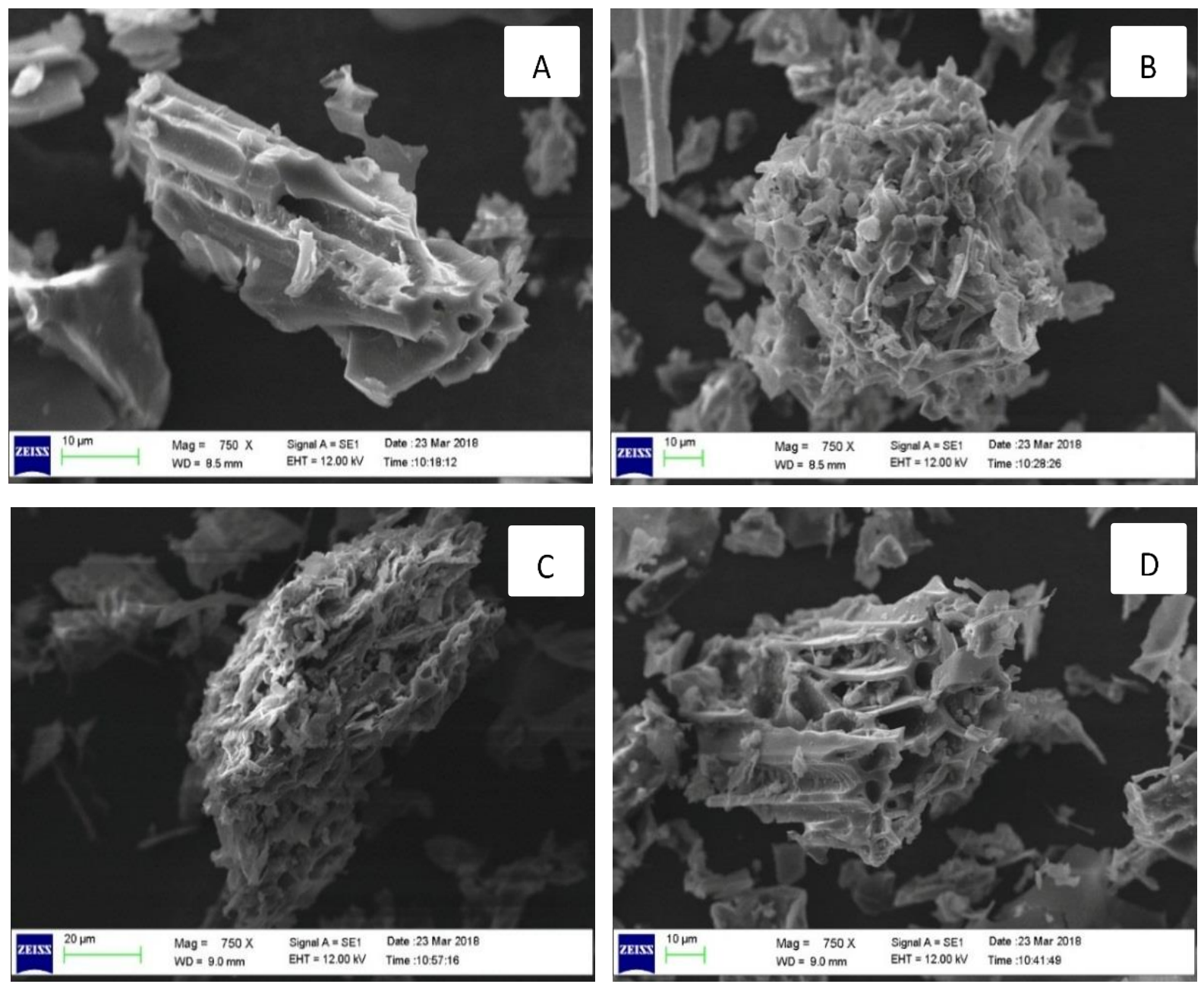

Figure 1. Morphology of activated carbon surface with 750x magnification (a) Activated carbon; (b) Activated carbon $+\mathrm{Cu}$; (c) Activated carbon $+\mathrm{Fe}$; and (d) Activated carbon $+\mathrm{Zn}$ ) 


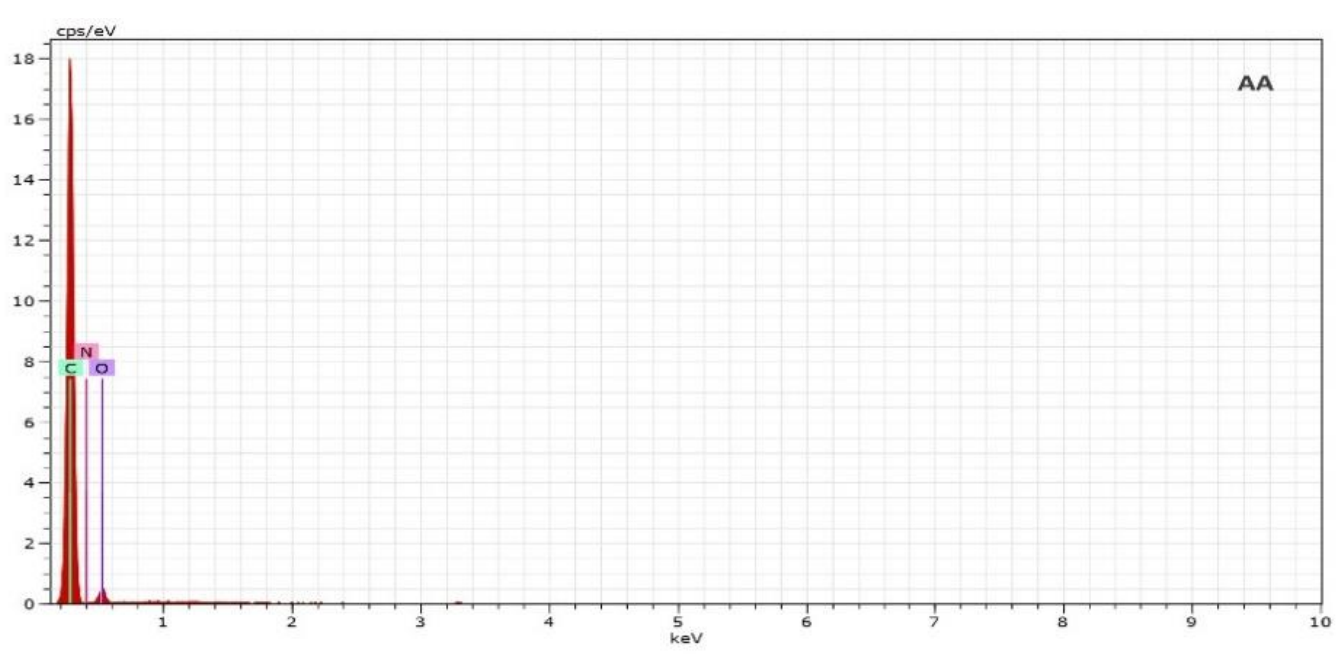

Figure 2. EDX observations on activated carbon without fertilizer addition

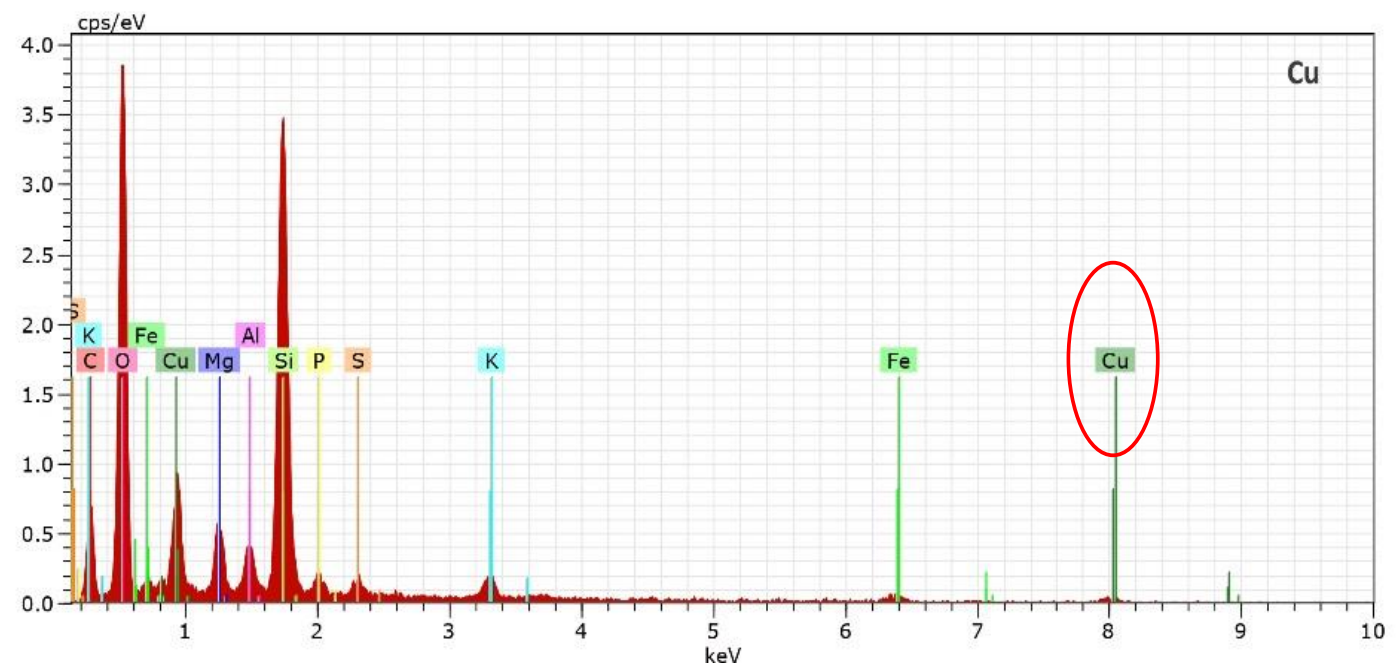

Figure 3. EDX observations on activated carbon with the addition of Cu fertilizer

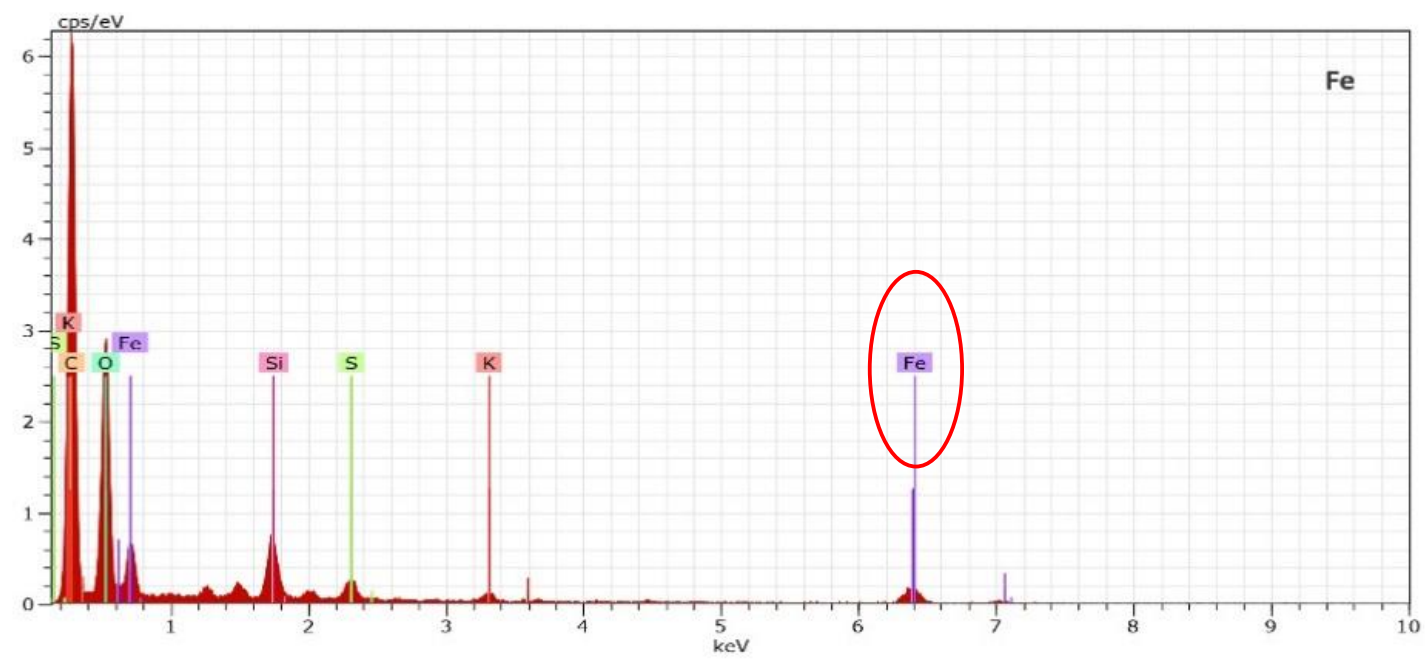

Figure 4. EDX observations on activated carbon with the addition of Fe fertilizer. 


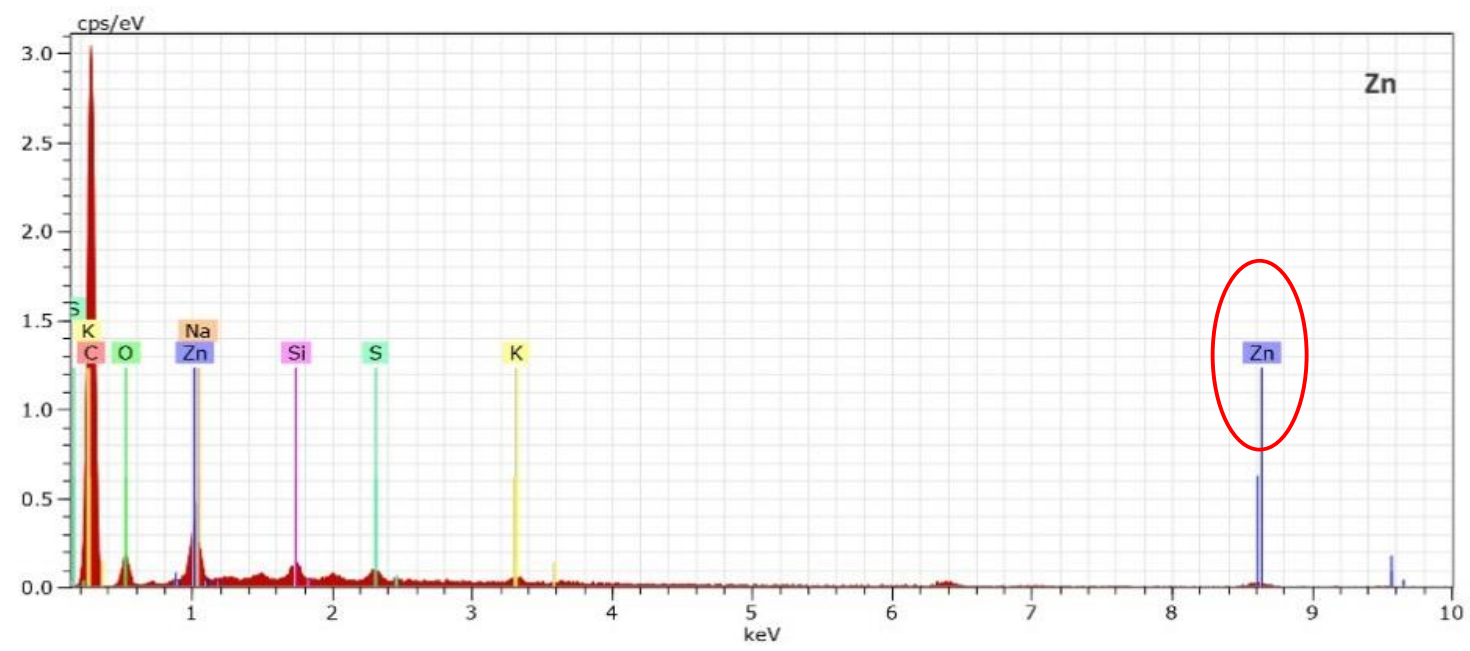

Figure 5. EDX observations on activated carbon with the addition of $\mathrm{Zn}$ fertilizer

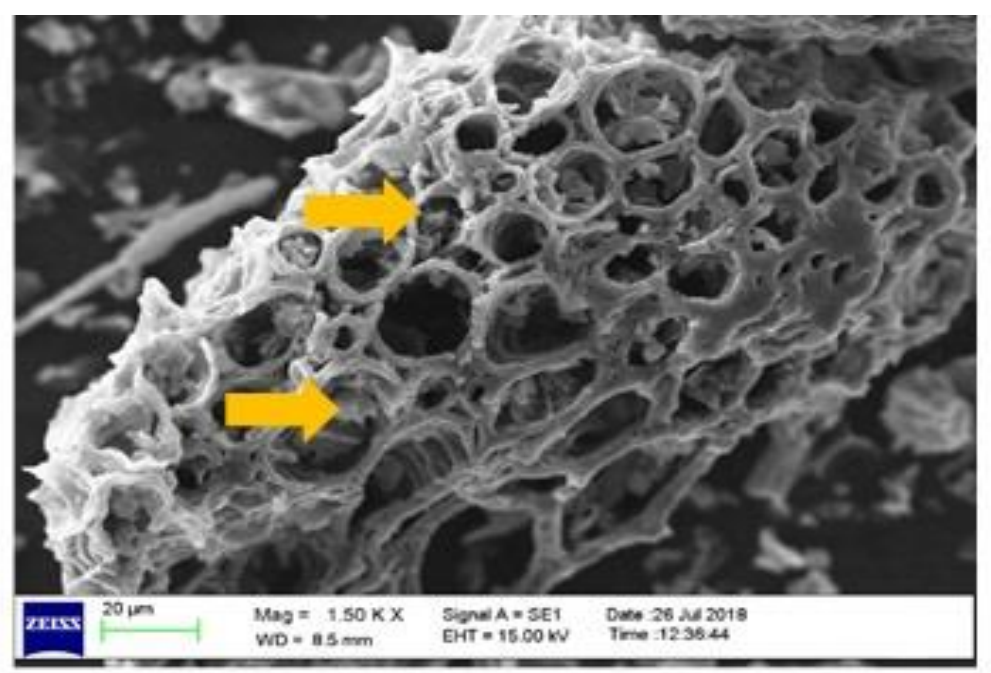

Figure 6. SEM observations on activated carbon + Cu were leaching 25 times

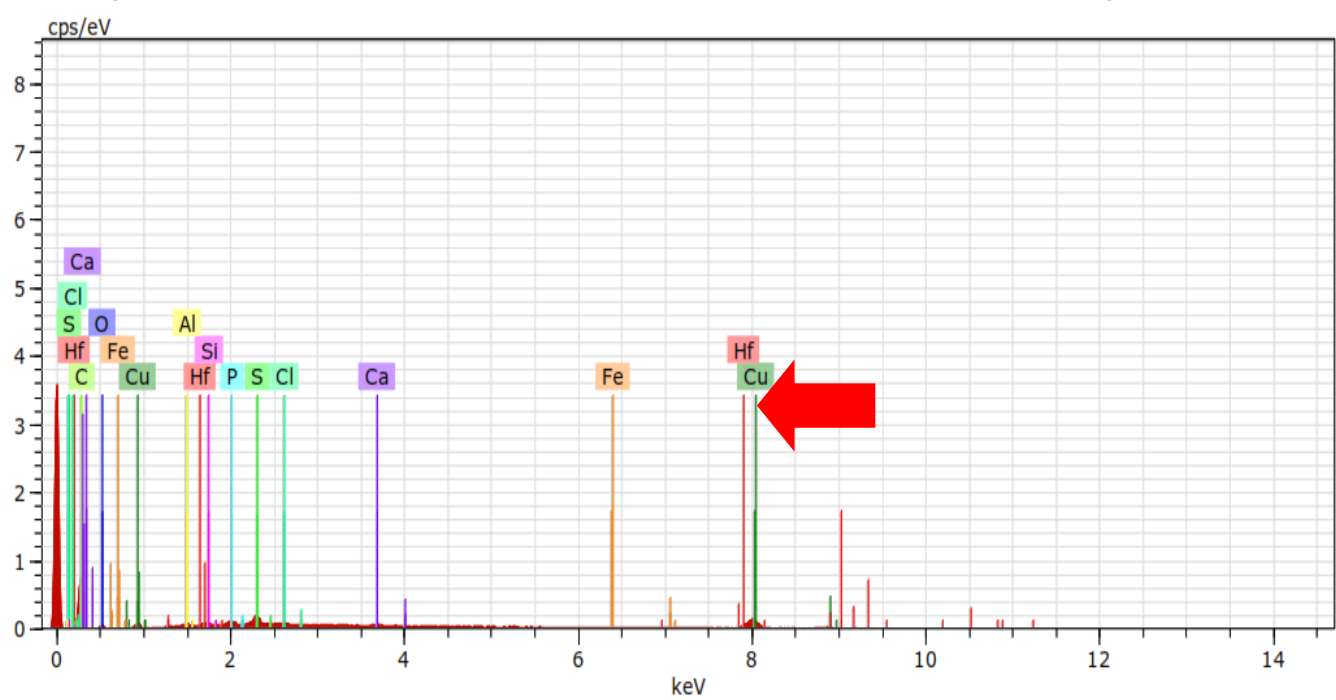

Figure 7. EDX observations on activated carbon + Cu were leaching 25 times. 


\section{Solubility test of slow release fertilizer}

This test aims to determine the release of $\mathrm{Cu}, \mathrm{Fe}$, and $\mathrm{Zn}$ in a slow release fertilizer. The test was carried out by extracting fertilizer with distilled water at extracting $0,20,40,60$, and 80 minutes. The test results are presented in Table 2. Based on Table 2, the Cu element has been able to be aroused in distilled water since the 0 minute matching time. The extracted $\mathrm{Cu}$ level was seen to be quite high at the beginning and then decreased and stabilized at the time of subsequent matching. Cu element solubility in 0 minutes was $100.51 \mathrm{ppm}$, then the decreasing happened in minute 20 (93.22 ppm), minute 40 (87.85 ppm), minute 60 (93.70 ppm) and minute 80 (94.00 ppm). In element solubility test, Fe has the lowest result in which it was $1.24 \mathrm{ppm}$ in minute $0,0.30 \mathrm{ppm}$ in minute $20,0.71 \mathrm{ppm}$ in minute $40,0.40 \mathrm{ppm}$ in minute 60 and $0.46 \mathrm{ppm}$ in minute 80 . While, solubility in $\mathrm{Zn}$ element was $15.76 \mathrm{ppm}$ in minute $0,15.60 \mathrm{ppm}$ in minute $20,12.78 \mathrm{ppm}$ in minute 40, $13.40 \mathrm{ppm}$ in minute 60 and $13.27 \mathrm{ppm}$ in minute 80 . From the result of the solubility test, it shows that the total amount of solubility for Cu was $469,28 \pm 4.49 \mathrm{ppm}$, Fe was $3.11 \pm 0.38 \mathrm{ppm}$ and $\mathrm{Zn}$ was $70.81 \pm 1.41 \mathrm{ppm}$.

\section{DISCUSSION}

\section{Activated Carbon Characteristics}

At the process of charcoal activation, there is a decreasing in rendemen. Decreasing rendemen at higher temperatures occurs due to the evaporation of water and the thermal decomposition of organic compounds (Yang et al., 2004). Luangkiattikhun et al. (2008) said that the maximum evaporation of $\mathrm{H}_{2} \mathrm{O}$ organic matter occurs at $220^{\circ} \mathrm{C}$, whereas at higher temperatures of $315-400{ }^{\circ} \mathrm{C}$ occurs cellulose decomposition and temperature above $400{ }^{\circ} \mathrm{C}$ occurs lignin decomposition. Increasing temperature causes an increasing amount of charcoal reaction to $\mathrm{CO}_{2}$ and $\mathrm{H}_{2} \mathrm{O}$. On the contrary, the resulting $\mathrm{C}$ was reduced so that the rendemen of the activated carbon produced is low. The decreasing of water content also occurs when the activation temperature was decreased, precisely at $350^{\circ} \mathrm{C}$ obtained $5.63 \%$ while the temperature of $600{ }^{\circ} \mathrm{C}$ obtained $3.67 \%$. Charcoal flying substance levels decreased after the activation process and decreased with increasing activation temperature. This occurs because, at high temperatures, decomposition of non-charcoal compounds such as $\mathrm{CO}_{2}, \mathrm{CO}, \mathrm{CH}_{4}$, and $\mathrm{H}_{2}$ can be perfect. While the ash content of activated corn cob charcoal did not show significant differences. Ash content in activated carbon can affect the adsorption because the pores in activated carbon will be filled by cations such as $\mathrm{K}, \mathrm{Na}, \mathrm{Ca}$, and $\mathrm{Mg}$.

Carbon content levels are strongly influenced by the levels of flying substances and ash content. The higher the flying substance and the ash content, the lower the charcoal content is bound. The value of charcoal content bound is directly proportional to the adsorption of the activated carbon, so that the greater the carbon content bound, the greater the ability of activated carbon to adsorb gas or solution (Sudrajat et al., 2005). This can be seen from the adsorption ability of activated carbon to iodine and methylene blue. Activated carbon has a higher adsorption capacity of iodine than charcoal. The adsorption capacity of corn cobs for iodine was 
$112.30 \mathrm{mg} \mathrm{g}^{-1}$, while the active adsorption ability of charcoal was $404.21 \mathrm{mg} \mathrm{g}^{-1}$. Increased adsorption ability shows that the charcoal atoms that form hexagonal crystals are increasing so that the pores formed between the crystallite layers also have a larger size. The same thing happened to the adsorption ability of activated carbon to methylene blue. The adsorption ability of methylene blue in corn cobs charcoal was $4.25 \mathrm{mg} \mathrm{g}^{-1}$, while the adsorption ability of activated carbon was $16.88 \mathrm{mg} \mathrm{g}^{-1}$. The high adsorption capacity of activated carbon to methylene blue shows that the hydrocarbon compounds found on the activated carbon surface have become more active and the bond between hydrogen and carbon is completely released so that there is a more active surface area (Pari et al., 2009). The increasing surface of the area and the total pore volume of activated carbon were affected by the activation process. This happened due to the opening of particles found in charcoal biomass so that the surface area becomes larger which is also followed by the total pore volume. The increase in temperature and time in the activation process results in many bonds of esters and polyester from the organic matter being released, so that more new pores are formed in activated carbon.

Based on Figure 2, Figure 3, Figure 4, and Figure 5 it was found that $\mathrm{Cu}, \mathrm{Fe}$, and $\mathrm{Zn}$ were found in activated carbon derived from corn cobs which had been soaked with $\mathrm{CuSO}_{4}, \mathrm{FeSO}_{4}$, and $\mathrm{ZnSO}_{4}$ solutions. Figure 2 shows EDX results from activated carbon without nutrient immersion treatment. This can be seen from the results of the analysis that did not show the typical peaks of nutrients but only contained elements of $\mathrm{C}, \mathrm{N}$ and $\mathrm{O}$. Figure 3 which is activated carbon + $\mathrm{Cu}$ shows the peak of $\mathrm{Cu}$ nutrients, as well as in Figure 4 namely activated carbon + Fe and Figure 5 which is the activated carbon $+Z n$ also shows the peak of $F e$ and $\mathrm{Zn}$. Overall nutrients added to activated carbon can be tied in activated carbon pores. This shows that activated carbon has the ability to bind or absorb added nutrients.

\section{Solubility test of slow release fertilizer}

Based on Table 2, the $\mathrm{Cu}$ element has been able to be aroused in distilled water since the 0 minute matching time. The extracted $\mathrm{Cu}$ level was seen to be quite high at the beginning and then decreased and stabilized at the time of subsequent matching. The same thing can also be seen in the solubility of Fe and $\mathrm{Zn}$, where the amount of $\mathrm{Fe}$ and $\mathrm{Zn}$ elements extracted at the beginning shows a higher amount, then experience stability at the time of matching 20,40,60, and 80 minutes. The result of the highest micro-nutrient solubility is found in activated carbon + Cu. While, the solubility of $\mathrm{Zn}$ nutrient was lower than $\mathrm{Cu}$ solubility, and then followed by the solubility of Fe. The results of the extraction of fertilizers with distilled water showed the number of elements available on the soil with neutral conditions which could be immediately adsorbed by plants. The $\mathrm{Cu}, \mathrm{Fe}$ and $\mathrm{Zn}$ levels extracted by distilled water were much lower compared to the total of these elements in activated carbon after immersion. This data shows that the release of nutrients occurs slowly. Several studies on activated carbon explain that the ability to adsorb is influenced by specific surface area and total pore volume. 
Buah et al. (2016) state that activated carbon made from corn cobs with a variety of specific surface area and pore volume can adsorb $\mathrm{Pb}$, $\mathrm{Cu}$, and $\mathrm{Cd}$ from wastewater. Furthermore, Aloko \& Adebayo (2007) revealed that charcoal from rice husk and corn cobs which were activated by oxidation methods were able to increase specific surface area and pore volume. This increasing can play an effective role in adsorbing the phosphorus elements that pollute the water body.

To find out whether or not the nutrients in the activated carbon are easily lost due to leaching, further testing was carried out by leaching activated carbon 25 times. Then, the fertilizer was dried and observed with SEM and EDX (Figure 6 and Figure 7). Figure 6 and Figure 7 shows that the $\mathrm{Cu}$ element was found in the washed activated carbon it has been done 25 times. This illustrates that $\mathrm{Cu}$ is strongly adsorbed in activated carbon and is not easily released. Tests were not carried out on other fertilizers because the data of each fertilizer extraction with distilled water showed almost the same results, i.e. very few elements were extracted compared to the total levels of elements in the fertilizer.

\section{CONCLUSIONS}

Agricultural waste in the form of corn cobs can be used as a fertilizer carrier by changing into activated carbon. The results of characterization indicated that the parameters for being a fertilizer carrier including the adsorption of iodine were $404.21 \mathrm{mg} \mathrm{g}^{-1}$, the adsorption of methylene blue $16.88 \mathrm{mg} \mathrm{g}^{-1}$, the pore volume was $0.19 \mathrm{cc} \mathrm{mg}^{-1}$ and surface area was $315.77 \mathrm{~m}^{2} \mathrm{~g}^{-1}$. Solubility test results showed that the activated carbon adsorption ability and the highest micro-nutrient solubility were found in $\mathrm{Cu}$, followed by $\mathrm{Zn}$, and $\mathrm{Fe}$. Adsorption ability and nutrient solubility are influenced by specific surface area and pore volume contained in activated carbon. High levels of solubility occurred at the beginning of shaking. Then, a steady decline occurred indicating that the rate of nutrient release in activated carbon occurs slowly. In addition, the results of the analysis on samples that have been washed as much as 25 times indicate that nutrients are still present in activated carbon both in the appearance of SEM and EDX.

\section{ACKNOWLEDGMENTS}

The authors would like to express they're thankful to the Ministry of Research, Technology and Higher Education for financial support through the PDP grant program with contract number 106/SP2H/LT/DPRM/2018.

\section{REFERENCES}

Adegbidi, H. G., Briggs, R. D., Volk, T. A., White, E. H., \& Abrahamson, L. P. (2003). Effect of organic amendments and slow-release nitrogen fertilizer on willow biomass production and soil chemical characteristics. Biomass and Bioenergy, 25(4), 389-398. doi: 10.1016/S09619534(03)00038-2

Al Tufaily, M. A. M., \& Al Qadi, Z. S. R. (2016). Preparation and Utilization of Corncob Activated Carbon for Dyes Removal from Aqueous Solutions: Batch and Continuous Study. Journal of Babylon, 24(3), 700-712.

Aloko, D. F., \& Adebayo, G. A. (2007). Production and Characterization of Activated Carbon from Agricultural Waste 
(Rice-husk and Corn-cob). Journal of Engineering and Applied Sciences, 2(2), 440-444.

Amin, M. T., \& Alazba, A. A. (2017). Comparative study of the absorptive potential of raw and activated carbon Acacia nilotica for Reactive Black 5 dye. Environmental Earth Sciences, 76(16), 17. doi: $10.1007 / \mathrm{s} 12665-017-6927-8$

Blaylock, A. D., Kaufmann, J., \& Dowbenko, R. D. (2005). Nitrogen fertilizer technologies. Western Nutrient Management, 6, 8-13. Retrieved from

BPS-Statistics of Lampung Province. (2013). Production of Paddy, Maize and Soybeans 2013. In BPS-Statistics of Lampung Province. doi: 10.1017/CBO9781107415324.004

Buah, W., MacCarthy, J., \& Ndur, S. (2016). Conversion of Corn Cobs Waste into Activated Carbons for Adsorption of Heavy Metals from Minerals Processing Wastewater. 4(4), 98-103. doi: 10.11648/j.ijepp.20160404.11

Bunyamin, Z., Efendi, R., \& Andayani, N. N. (2013). Utilization of corn waste for the animal feed industry. Seminar Nasional Inovasi Teknologi Pertanian, pp. 153-166.

Clough, T. J., \& Condron, L. M. (2010). Biochar and the Nitrogen Cycle: Introduction. Journal of Environment Quality, 39(4), 1218. doi: $10.2134 /$ jeq2010.0204

Du, C. W., Zhou, J. M., \& Shaviv, A. (2006). Release characteristics of nutrients from polymer-coated compound controlled release fertilizers. Journal of Polymers and the Environment, 14(3), 223-230. doi: 10.1007/s10924-006-0025-4

Graham, R. L., Nelson, R., Sheehan, J., \& Perlack, R. D. \& Wright, L. L. (2007). Current and potential U.S. corn stover supplies. Agronomy Journal, 99(1), 1-11. doi: 10.2134/agronj2005.0222

Hayashi, K., Gummert, M., \& Zaini, Z. (2013).
Biochar for future food security: learning from experiences and identifying research priorities. In K. Hayashi (Ed.), National Workshop on Biochar for Food Security: Learning from Experiances and Identifying (pp. 37-46). Indonesia: IRRI.

Kamala, C. T., Balaram, V., Dharmendra, V., Subramanyam, K. S. V., \& Krishnaiah, A. (2014). Application of Microwave Plasma Atomic Emission Spectrometry (MP-AES) for environmental monitoring of industrially contaminated sites in Hyderabad City. Environmental Monitoring and Assessment, 186(11), 7097-7113. doi: 10.1007/s10661-0143913-4

Keech, O., Carcaillet, C., \& Nilsson, M. C. (2005). Adsorption of allelopathic compounds by wood-derived charcoal: The role of wood porosity. Plant and Soil, 272(1-2), 291300. doi: 10.1007/s11104-004-5485-5

Laird, D., Fleming, P., Wang, B., Horton, R., \& Karlen, D. (2010). Biochar impact on nutrient leaching from a Midwestern agricultural soil. Geoderma, 158(3-4), 436-442. doi: 10.1016/j.geoderma.2010.05.012

Luangkiattikhun, P., Tangsathitkulchai, C., \& Tangsathitkulchai, M. (2008). Nonisothermal thermogravimetric analysis of oil-palm solid wastes. Bioresource Technology, 99(5), 986-997. doi: 10.1016/j.biortech.2007.03.001

McCutcheon, J., \& Samples, D. (2002). Grazing Corn Residues. Extension Fact Sheet Ohio State University Extension. US. ANR10-02. Munawaroh, I. (2012). Utilization of corncob as adsorbent rhodamin $b$ and methanil yellow. UIN Sunan Kalijaga Yogyakarta.

Namgay, T., Singh, B., \& Singh, B. P. (2010). Influence of biochar application to soil on the availability of $\mathrm{As}, \mathrm{Cd}, \mathrm{Cu}, \mathrm{Pb}$, and $\mathrm{Zn}$ to maize (Zea mays L.). Australian Journal of Soil Research, 48(6-7), 638-647. doi: 


\subsection{1/SR10049}

National Standardization Agency of Indonesia. (1995). Technical activated carbon. Indonesia.

Pari, G., Widayati, D. T., \& Yoshida, M. (2009). The quality sawdust activated charcoal. Jurnal Penelitian Hasil Hutan, 27(4), 381398. doi: 10.20886/jphh.2009.27.4.381398

Rao, M. M., Ramana, D. K., Seshaiah, K., Wang, M. C., \& Chien, S. W. C. (2009). Removal of some metal ions by activated carbon prepared from Phaseolus aureus hulls. Journal of Hazardous Materials, 166(2-3), 1006-1013. doi: 10.1016/j.jhazmat.2008.12.002

Shaviv, A. (2001). Advances in controlled release of fertilizers. Advances in Agronomy, 71, 1-49. doi: 10.1016/S00652113(01)71011-5

Singh, P. P., \& Ambika. (2018). New Polymer Nanocomposites for Environmental Remediation. New Polymer Nanocomposites for Environmental Remediation, (1), 223-241.

Sudrajat, R., Anggorowati, \& Setiawan, D. (2005). Manufacturing of activated charcoal from (Jatropha curcas L.) wood. Jurnal Penelitian Hasil Hutan, 23(4), 299315.

Trenkel, M. E. (2010). Slow and Controlled Release and Stabilized Fertilizers: An Option for Enhancing Nutrient Use
Efficiency in Agriculture. In Climate Change 2013 - The Physical Science Basis (Vol. 53). doi: 10.1017/CBO9781107415324.004

Tsai, W. T., Chang, C. Y., \& Lee, S. L. (1998). A low cost adsorbent from agricultural waste corn cob by zinc chloride activation. 64 , 211-217. doi: 10.1016/S09608524(97)00168-5

Utomo, W. H., Widowati, Guritno, B., \& Soehono, L. A. (2012). The Effect of Biochar on the Growth and N Fertilizer Requirement of Maize (Zea mays L.) in Green House Experiment. Journal of Agricultural Science, 4(5), 255-262. doi: 10.5539/jas.v4n5p255

Yang, H., Yan, R., Chin, T., Liang, D. T., Chen, H., \& Zheng, C. (2004). Thermogravimetric Analysis-Fourier Transform Infrared Analysis of Palm Oil Waste Pyrolysis. Energy \& Fuels, 18(6), 1814-1821. doi: 10.1021/ef030193m

Yang, R., Liu, G., Xu, X., Li, M., Zhang, J., \& Hao, $X$. (2011). Surface texture, chemistry and adsorption properties of acid blue 9 of hemp (Cannabis sativa L.) bast-based activated carbon fibers prepared by phosphoric acid activation. Biomass and Bioenergy, 35(1), 437-445. doi: 10.1016/j.biombioe.2010.08.061

Zych, D. (2008). The Viability of Corn Cobs As a Bioenergy Feedstock. West Central Research and Outreach Center, 1-25. 